\title{
Maternal genes and pathways affecting birth weight and weaning weight traits in sheep: A GWAS and pathway enrichment analysis
}

Mehdi Esmaeilifard ( $\nabla$ mehdi.esmaeilifard@gmail.com )

Sari Agricultural Sciences and Natural Resources University https://orcid.org/0000-0001-7509-5030

\section{Seyed Hasan Hafezian}

Sari Agricultural Sciences and Natural Resources University

\section{Mohsen Gholizadeh}

Sari Agricultural Sciences and Natural Resources University

Rostam Abdollahi-Arpanahi

University of Florida

Research article

Keywords: Ewe productivity, Maternal genes, Maternal pathways, GWAS, Gene set enrichment

Posted Date: February 11th, 2020

DOI: https://doi.org/10.21203/rs.2.23075/v1

License: (c) (i) This work is licensed under a Creative Commons Attribution 4.0 International License.

Read Full License

Version of Record: A version of this preprint was published at Frontiers in Genetics on July 28th, 2021.

See the published version at https://doi.org/10.3389/fgene.2021.710613. 
$1 \quad$ Maternal genes and pathways affecting birth weight and weaning

2 weight traits in sheep: A GWAS and pathway enrichment analysis

\author{
Mehdi Esmaeilifard ${ }^{1}$, Seyed Hasan Hafezian², Mohsen Gholizadeh ${ }^{2}$, Rostam Abdollahi- \\ Arpanahi $^{3}$ \\ ${ }^{1}$ Ph.D. Graduate, Sari Agricultural Sciences and Natural Resources University (SANRU), Sari, Iran \\ ${ }^{1,2}$ Associate Professor, Sari Agricultural Sciences and Natural Resources University (SANRU), Sari, Iran \\ ${ }^{3}$ Research Assistant, Department of Animal Sciences, University of Florida, Gainesville, FL, United States
}

9

Background: Ewe productivity is considered as the most important economic trait in sheep meat production. Due to very limited reports, the objective of this study was the application of alternative GWAS approaches followed by gene set enrichment analysis (GSEA) on the maternal genome to unravel the genomic architecture underlying ewe productivity in Iranian Baluchi sheep. Six maternal composite traits including progeny birth weight (PBW), litter mean weight at birth (LMWB), total litter weight at birth (TLWB), progeny weaning weight (PWW), litter mean weight at weaning (LMWW) and total litter weight at weaning (TLWW) were studied.

Results: Genes such as RDX, FDX1, ARHGAP20, ZC3H12C, THBS1, and EPG5 on OAR6, OAR7, OAR15, and OAR23 were identified for composite traits at birth. The genes are involved in pregnancy, including autophagy in the placenta, progesterone production by the placenta, maternal immune response and placenta formation. Some maternal pathways, related to calcium ion transport, signal transduction, neurogenesis, and immune response were also identified for birth weight traits. Moreover, many genes including NR2C1, VEZT, HSD17B4, RSU1, CUBN, VIM, PRLR, and FTH1 were located on OAR2, OAR3, OAR5, OAR7, OAR13, OAR16, and OAR25 identified as maternal genes affecting weaning weight traits. Most of the identified genes 
24 were involved in mammary glands development and milk components production. Also, many GO

25 terms related to protein processing and transport, ion transport and homeostasis, proteins and lipid

26 phosphorylation, and phospholipid translocation were identified in association with weaning

27 weight traits.

28 Conclusions: The results of the present study revealed that calcium ion homeostasis and transport

29 and the maternal immune system could have an important role in progeny's birth weight. Also, the

30 results showed that genes and pathways affecting mammary glands development during pregnancy

31 and milk components production have the most impact on lambs weaning weight. These findings

32 contribute to a better understanding of the genetic architecture of the studied traits and providing

33 opportunities for improving ewe productivity via marker-assisted selection.

34 Keywords: Ewe productivity, Maternal genes, Maternal pathways, GWAS, Gene set enrichment

\section{Background}

In sheep breeding, ewe productivity is the most important trait affecting profitability and genetic

37 progress in this complex trait can lead to more efficient lamb production [1]. In some countries

38 such as Iran, where meat is the main sheep product, the productivity of the ewe flock has the

39 greatest influence on profitability per ewe [2]. An increase in meat output in the sheep production

40 system could be achieved by increasing the number and weight of lambs weaned per ewe within a

41 specific year [3]. Ewe productivity, which was defined as total lamb weight weaned (TLWW) per

42 ewe, is a most common composite trait that is affected by many cooperative components linked to

43 reproduction and growth, including age at puberty, ovulation, pregnancy, parturition, lactation,

44 mothering ability and lamb survival and growth [4] and often is regarded as an overall measure of

45 lamb production capacity by ewes [5]. Composite traits are a combination of growth and 
46 reproductive traits. Therefore, genetic improvement of ewe productivity is a key target in sheep

47 breeding programs [3]. Common composite reproductive traits in sheep are total litter weight at 48 birth (TLWB) and total litter weight at weaning (TLWW) and have the excellence of being better 49 coordinate to the market, where producers are paid on a per kilogram and not on a per head [6].

50 Although estimates of genetic parameters have been reported for composite traits of different 51 Iranian sheep breeds [6, 7], reports on genes and pathways affecting these traits are limited. To our 52 knowledge, there is only one published report of genes and genomic regions associated with 53 composite traits in sheep [6]. A whole-genome scan carried out by the authors and five genes 54 neighboring the top SNPs (on OAR2, OAR3, OAR15, and OAR16), including TEX12, BCO2, $55 W D R 70, I N H B E$, and $I N H B C$ reported as possible candidate genes affecting composite traits of 56 the Lori-Bakhtiari sheep.

57 Due to the strict threshold used in Genome-wide association studies (GWAS) to finding significant 58 SNPs, several poorly associated SNPs are always ignored. An alternative strategy is to add gene 59 set analysis as a complement approach after GWAS [8]. In this approach, a set of genes with some 60 common functional features (e.g. being a member of a specific pathway) which are identified by 61 significant (with comfortable threshold) SNPs of GWAS, is tested for over-representation in a 62 specific pathway [9]. Recently a growing interest in gene set enrichment analysis has been 63 observed in dairy cattle $[8,10,11]$. However, there are no published reports of gene set analysis 64 of sheep GWAS dataset.

65 Baluchi sheep breed is the largest sheep breed in Iran and well adapted to a wide range of arid 66 subtropical environments from north-east to south-east of the country [12]. Due to very limited 67 reports on maternal genes and pathways affecting composite traits, the objective of this study was 
68 to conduct GWAS and gene set enrichment analysis (GSEA) to unravel the genomic architecture

69 underlying ewe productivity in Iranian Baluchi sheep.

\section{Results}

\section{GWA analysis of the maternal composite traits at birth}

72 For these set of traits, we looked for maternal genes and pathways that influence progeny's birth

73 weight during pregnancy. The results of GWAS analysis are shown in a Circular Manhattan plot

74 in Figure 1. Nine significant SNPs located on chromosomes OAR6, OAR7, OAR15 and OAR23

75 were identified for ewe reproductive traits at birth (Table 1). Three common significant SNPs, 76 rs428350449, rs422482383 and rs423274340 on OAR15 (19.7-20.3 Mb) harbors four candidate 77 genes, RDX, FDX1, ZC3H12C, and ARHGAP20. SNPs rs422482383 and rs423274340 were

78 significantly associated with the three traits in both GWAS approaches which rs422482383

79 identified within the ovine known gene ARHGAP20. Another SNP (rs427207318) located on 80 OAR15 at 69.5 Mb had a significant association with LMWB trait which was not contained any 81 gene. In addition, we found three marginally significant SNPs (rs408063438, rs399067974, and 82 rs400684038) located on OAR7 (30.2-35.1 Mb) associated with PBW trait. 


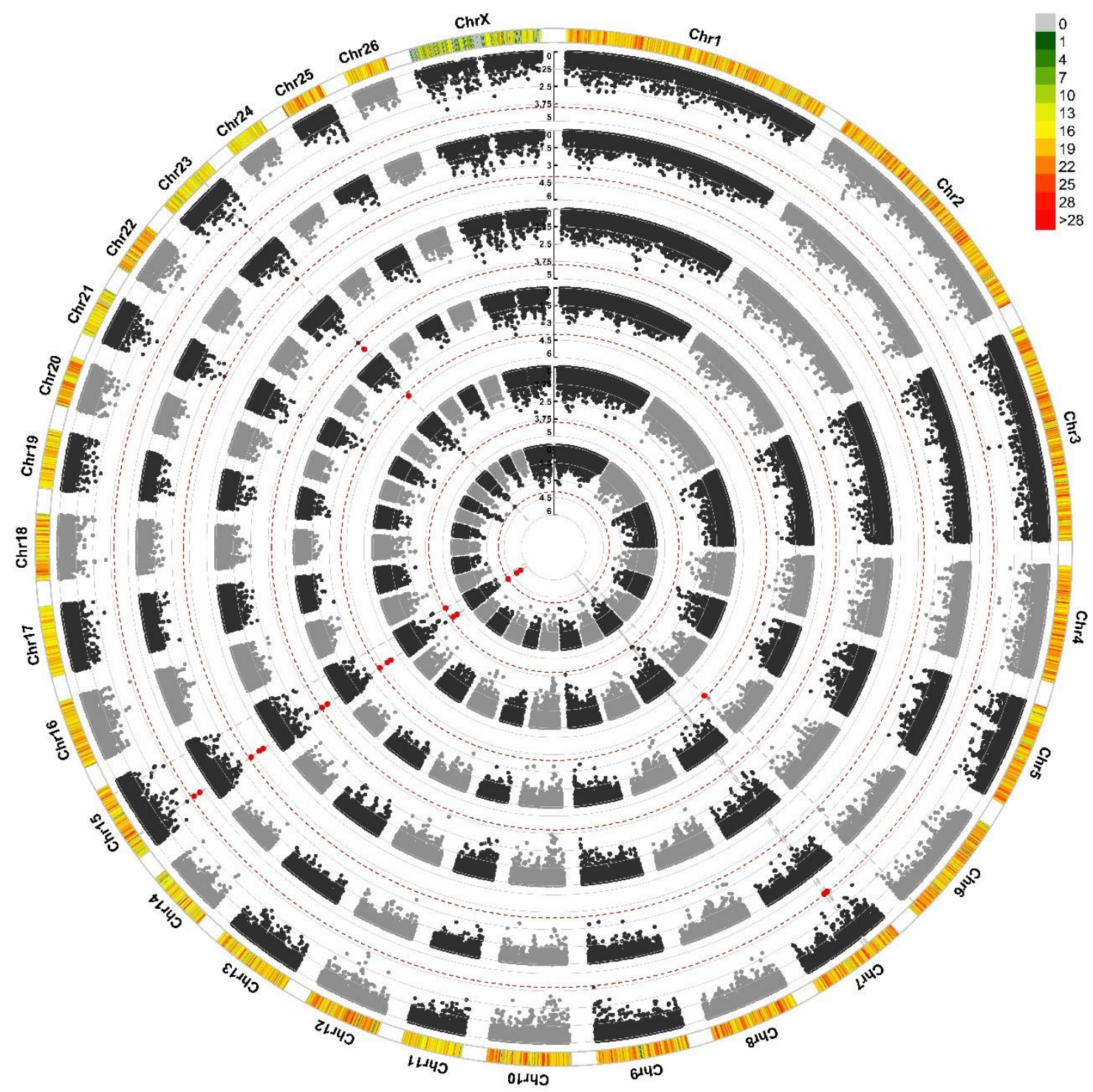

Fig. 1 Circular Manhattan plot for associations of SNPs with ewe composite traits at birth by two GWAS approaches. The 6 circles from outside to inside represent Progeny Birth Weight (PBW): pGWAS and eGWAS; Total Litter Weight at Birth (TLWB): pGWAS and eGWAS; Litter Mean Weight at Birth (LMWB): pGWAS and eGWAS. X-axis: SNPs

87 positions on chromosomes, Y-axis: -Log10 P-value. The dashed lines indicate the threshold for statistical significance $88\left(\mathrm{P}<10^{-4}\right)$. The outermost circle show SNPs density in $1 \mathrm{Mb}$ window for each chromosome. pGWAS: GWAS using 89 phenotypes as response variable; eGWAS: GWAS using EBVs as response variable. the TTBK2 gene. Also, two SNPs (rs430043751 and rs426428997) on OAR23 and OAR6 were 
92 significantly related to TLWB trait. SNP rs430043751 on OAR23 identified in both GWAS

93 approaches harbors six genes. This SNP was very close to the threshold line for PBW and LMWB

94 traits in both GWAS approaches. SNP rs426428997 on OAR6 did not contain any gene in the

95 searched region.

96 Table 1 SNPs significantly associated with ewe composite traits at birth in Baluchi sheep.

\begin{tabular}{|c|c|c|c|c|c|c|}
\hline $\mathrm{Chr}$ & SNP & Position & Genes in $300 \mathrm{~kb}$ interval & $\begin{array}{l}\text { Analysis } \\
\text { method }\end{array}$ & Adjusted P-value & Trait(s) \\
\hline 15 & rs 422482383 & 20125491 & $\begin{array}{l}\text { RDX, FDX1, } \\
\text { ARHGAP20 (Within) }\end{array}$ & $\begin{array}{l}\text { pGWAS } \\
\text { \& eGWAS }\end{array}$ & $\begin{array}{l}2.06 \times 10^{-5} \\
3.34 \times 10^{-6}\end{array}$ & $\begin{array}{l}\text { PBW, TLWB } \\
\& \text { LMWB }\end{array}$ \\
\hline 15 & rs423274340 & 20304472 & ARHGAP20 & $\begin{array}{l}\text { pGWAS } \\
\& \text { eGWAS }\end{array}$ & $\begin{array}{l}6.43 \times 10^{-5} \\
8.20 \times 10^{-6}\end{array}$ & $\begin{array}{l}\text { PBW, TLWB } \\
\& \text { LMWB }\end{array}$ \\
\hline 15 & rs 428350449 & 19740174 & ZC3H12C, RDX, FDX1 & eGWAS & $6.34 \times 10^{-5}$ & $\begin{array}{l}\text { PBW \& } \\
\text { LMWB }\end{array}$ \\
\hline 15 & rs427207318 & 69550331 & Without gene & pGWAS & $8.43 \times 10^{-5}$ & LMWB \\
\hline 7 & rs 408063438 & 30207038 & Without gene & pGWAS & $9.37 \times 10^{-5}$ & PBW \\
\hline 7 & rs399067974 & 32062261 & ZCRB1, THBS1, FSIP1 & pGWAS & $9.37 \times 10^{-5}$ & PBW \\
\hline 7 & rs 400684038 & 35113511 & $\begin{array}{l}\text { ZNF106, SNAP23, } \\
\text { LRRC57, HAUS2, } \\
\text { STARD9, CDAN1, } \\
\text { TTBK2 (Within), } \\
\text { UBR1, TMEM62 }\end{array}$ & pGWAS & $9.37 \times 10^{-5}$ & PBW \\
\hline 23 & rs430043751 & 46167308 & $\begin{array}{l}\text { EPG5, PSTPIP2, } \\
\text { ATP5F1A, HAUS1, } \\
\text { RNF165, LOXHD1 }\end{array}$ & $\begin{array}{l}\text { pGWAS } \\
\& \text { eGWAS }\end{array}$ & $\begin{array}{l}2.52 \times 10^{-5} \\
5.21 \times 10^{-5}\end{array}$ & TLWB \\
\hline 6 & rs426428997 & 109147722 & Without gene & eGWAS & $7.20 \times 10^{-5}$ & TLWB \\
\hline
\end{tabular}

97 Chr: Chromosome number; pGWAS: GWAS using phenotypes as response variable; eGWAS: GWAS using EBVs as response variable; PBW:

98 Progeny Birth Weight; TLWB: Total Litter Weight at Birth; LMWB: Litter Mean Weight at Birth. P-values are presented just for the first trait in

99 the Trait(s) column. P-values are adjusted based on the Genomic Control value.

100 GWA analysis of the maternal composite traits at weaning

101 For maternal composite traits at weaning, we looked for maternal genes and pathways that 102 influence progeny's weaning weight. The circular Manhattan plot for associations of SNP markers 103 with the traits for both GWAS approaches is shown in Figure 2. 


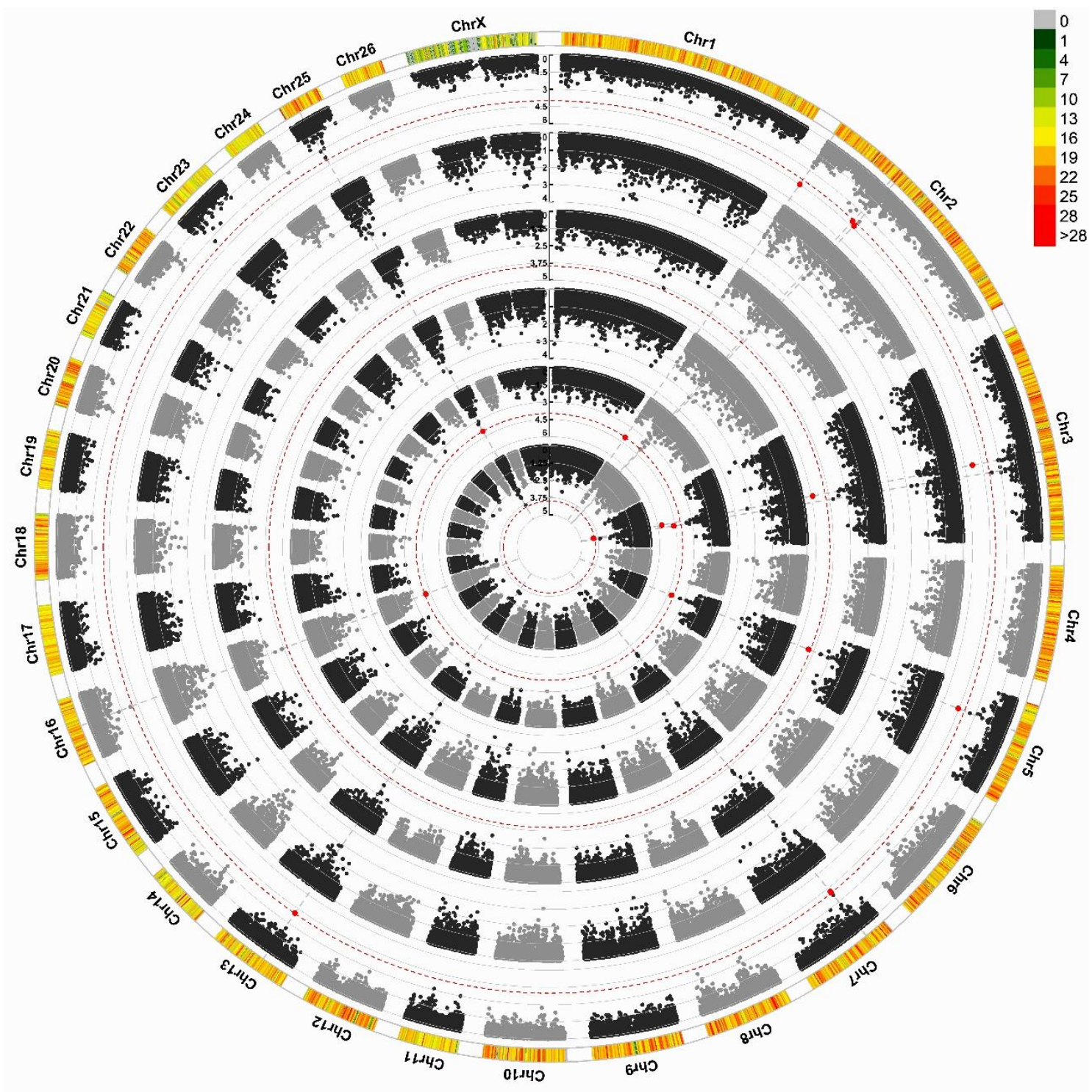

Fig. 2 Circular Manhattan plot for associations of SNPs with ewe composite traits at weaning by two GWAS approaches. The 4 circles, from outside to inside, represent Progeny Weaning Weight (PWW): pGWAS and eGWAS;

107 Total Litter Weight at Weaning (TLWW): pGWAS and eGWAS; Litter Mean Weight at Weaning (LMWW): pGWAS and eGWAS. X-axis: SNPs positions on chromosomes, Y-axis: -Log10 P-value. The dashed lines indicate the threshold for statistical significance $\left(\mathrm{P}<10^{-4}\right)$. The outermost circle show SNPs density in $1 \mathrm{Mb}$ window for each

110 chromosome. pGWAS: GWAS using phenotypes as response variable; eGWAS: GWAS using EBVs as response 111 variable. 
112 A total of 10 significant SNPs located on OAR2, OAR3, OAR5, OAR7, OAR13, OAR16 and

113 OAR25 were related to maternal composite traits at weaning (Table 2).

114 Table 2 SNPs significantly associated with ewe composite traits at weaning in Baluchi sheep.

\begin{tabular}{|c|c|c|c|c|c|c|}
\hline Chr & SNP & Position & $\begin{array}{l}\text { Genes in } 300 \mathrm{~kb} \\
\text { interval }\end{array}$ & $\begin{array}{l}\text { Analysis } \\
\text { method }\end{array}$ & Adjusted P-value & Trait(s) \\
\hline 3 & rs428404187 & 131255497 & $\begin{array}{l}\text { NDUFA12, NR2C1, } \\
\text { FGD6, VEZT (Within), } \\
\text { MIR331, METAP2 }\end{array}$ & $\begin{array}{l}\text { pGWAS } \\
\& \text { eGWAS }\end{array}$ & $\begin{array}{l}4.72 \times 10^{-6} \\
8.60 \times 10^{-5}\end{array}$ & $\begin{array}{l}\text { PWW, TLWW } \\
\& \text { LMWW }\end{array}$ \\
\hline 5 & rs398620273 & 32383306 & $\begin{array}{l}\text { HSD17B4 (+461434), } \\
\text { DMXL1, DTWD2 } \\
\text { (Within) }\end{array}$ & pGWAS & $2.72 \times 10^{-5}$ & $\begin{array}{l}\text { PWW, TLWW } \\
\text { \& LMWW }\end{array}$ \\
\hline 2 & rs412011189 & 1426911 & EIPR1 (TSSC1) & pGWAS & $3.39 \times 10^{-5}$ & $\begin{array}{l}\text { PWW \& } \\
\text { LMWW }\end{array}$ \\
\hline 2 & rs411656768 & 81968762 & NFIB & pGWAS & $4.74 \times 10^{-5}$ & PWW \\
\hline 7 & rs430218107 & 23778602 & $\begin{array}{l}\text { EDDM3B, ANG1, } \\
\text { RNASE1, RNASE6, } \\
\text { RNASE4, ANG2, } \\
\text { UQCRFS1, RNASE12, } \\
\text { RNASE11, RNASE9, } \\
\text { RNASE10, PIP4P1, } \\
\text { APEX1, OSGEP, } \\
\text { KLHL33, TEP1, } \\
\text { PARP2, RPPH1, } \\
\text { SNORA79B, } \\
\text { CCNB1IP1, TTC5, } \\
\text { OR11H4, OR11H7, } \\
\text { OR11H6 }\end{array}$ & pGWAS & $7.42 \times 10^{-5}$ & PWW \\
\hline 2 & rs403459195 & 77075145 & RPLP0 (+435045) & pGWAS & $7.88 \times 10^{-5}$ & PWW \\
\hline 13 & rs401393221 & 30320719 & $\begin{array}{l}\text { PTER, C1q13, RSU1 } \\
\text { (within), CUBN, VIM } \\
(-426809)\end{array}$ & pGWAS & $9.50 \times 10^{-5}$ & PWW \\
\hline 3 & rs404069303 & 143726957 & SNORA62 & pGWAS & $1.90 \times 10^{-5}$ & LMWW \\
\hline 16 & rs409558668 & 39225407 & $\begin{array}{l}\text { PRLR, AGXT2, } \\
\text { DNAJC21, BRIX1, } \\
\text { RAD1, TTC23L } \\
\text { (Within), RAI14 }\end{array}$ & pGWAS & $7.95 \times 10^{-5}$ & LMWW \\
\hline 25 & rs405045517 & 16553906 & $\begin{array}{l}\text { CDK1, FTH1, } \\
\text { RHOBTB1 (within) }\end{array}$ & pGWAS & $9.89 \times 10^{-5}$ & LMWW \\
\hline
\end{tabular}

115 Chr: Chromosome number; pGWAS: GWAS using phenotype; eGWAS: GWAS using EBVs; PWW: Progeny Weaning Weight; TLWW: Total

116 Litter Weight at Weaning; LMWW: Litter Mean Weight at Weaning. P-values are presented just for the first trait in the Trait(s) column. In a few

117 spatial cases, genes with a distance more than 300kb from significant SNP are also shown. P-values are adjusted based on the Genomic Control 118 value. 
119 The results of two GWAS approaches showed similar profiles with two common significant SNPs on OAR3 (rs428404187) and OAR5 (rs398620273). The most significant SNP was rs428404187

$121\left(\mathrm{p}=4.72 \times 10^{-6}\right)$, which is located at $131.2 \mathrm{Mb}$ on OAR3 and was significant for the three composite 122 traits at weaning in pGWAS approach. This SNP had a significant association with LMWW in 123 both GWAS approaches and is located within the VEZT gene. Other SNPs were significant just in 124 pGWAS approach. For PWW and TLWW traits, there were no significant SNPs using eGWAS 125 and for LMWW only one SNP located on OAR3 identified by this approach. Another common 126 significant SNP (rs398620273) on OAR5 was identified for the three composite traits at weaning 127 and was located within the DTWD2 gene. SNP rs412011189 on OAR2 was associated with PWW 128 and LMWW and was close to EIPRI (TSSC1) gene. In addition, we found four SNPs on OAR2 129 (rs411656768 and rs403459195), OAR7 (rs430218107), and OAR13 (rs401393221) that were 130 significantly associated with PWW. A SNP on OAR7 was located on $23.7 \mathrm{Mb}$ and harbors 24 131 genes in $300 \mathrm{~Kb}$ interval, which seven of them were RNase genes. A SNP on OAR13 was located 132 in the RSU1 gene, as well as, VIM gene is located downstream of this SNP at a distance of 4.2kb.

133 Three significant SNPs related to LMWW were identified on OAR3 (rs404069303), OAR16 134 (rs409558668), and OAR25 (rs405045517). A SNP located on OAR16 harbors seven genes. This 135 SNP located in ovine Known gene TTC23L. Additionally, the Prolactin receptor (PRLR) gene 136 located close to this SNP. Another significant SNP was rs405045517 located on OAR25 and 137 harbor three genes $(C D K 1, F T H 1$, and $R H O B T B 1)$ in the searched region. This SNP located within 138 the RHOBTB1 gene. Also, the FTH1 gene is located close to this SNP.

\section{Gene-Set enrichment Analysis}

140 The results of GWAS were complemented with gene set enrichment analysis using the GO 141 database. In GSA we looked for maternal pathways affecting lambs' weights at birth and weaning. 
142 In total, 23,462 of 45,342 SNPs tested in the GWAS, were located within or $15 \mathrm{~kb}$ upstream or

143 downstream of 15815 annotated genes in the Oar.v3.1 ovine genome assembly. On average, 1310

144 out of 15815 genes (ranging between 1,291 for LMWW to 1,351 for TLWW) contained at least

145 one significant SNP (P-value $\leq 0.05)$ and defined as significantly associated genes with maternal

146 composite traits. GO terms with a nominal P-value $\leq 0.01$ were reported as significant terms.

147 GWAS results using direct phenotypes (pGWAS) were used for the analysis and each trait was 148 analyzed separately.

\section{Gene-set enrichment analysis of the maternal composite traits at birth}

150 Table 3 shows a set of GO terms that were significantly $(\mathrm{P} \leq 0.01)$ enriched with genes associated

151 with maternal composite traits at birth. Several GO terms related to neural system showed an 152 overrepresentation of significant genes, including postsynaptic density (GO:0014069), Schaffer 153 collateral-CA1 synapse (GO:0098685), glutamatergic synapse (GO:0098978), synapse 154 (GO:0045202), neuron projection development (GO:0031175), neurogenesis (GO:0022008), and 155 many others terms that were not included in Table5 (see Additional file1: Table S1-Table S3). We 156 identified calcium ion transport (GO:0000045) associated with the composite traits at birth. Also, 157 calcium channel inhibitor activity (GO:0019855) showed an overrepresentation of significant 158 genes associated with TLWB. Many GO terms related to immune system also showed significant 159 enrichment of genes associated with composite traits at birth, including cellular response to 160 chemokine (GO:1990869), positive regulation of T-helper 1 type immune response (GO:0002827), 161 positive regulation of interleukin-12 production (GO:0032735), and positive regulation of T cell 162 activation (GO:0050870). Several significant GO terms were related to the signaling process. 
Table 3 Most related Gene Ontology (GO) terms significantly ( $\mathrm{p} \leq 0.01$ ) enriched using genes associated with maternal composite traits at birth.

\begin{tabular}{|c|c|c|c|c|c|c|}
\hline Trait & Cat. No. & Term & $\begin{array}{l}\text { No. of genes } \\
\text { in the term }\end{array}$ & $\begin{array}{l}\text { No. of } \\
\text { sig. genes }\end{array}$ & $P_{\text {_value }}$ & Ont \\
\hline \multirow[t]{13}{*}{ PBW } & GO:0014069 & postsynaptic density & 82 & 21 & $2.36 \mathrm{E}-06$ & $\mathrm{CC}$ \\
\hline & GO:0098685 & Schaffer collateral - CA1 synapse & 42 & 12 & $1.10 \mathrm{E}-04$ & $\mathrm{CC}$ \\
\hline & GO:0098978 & glutamatergic synapse & 165 & 28 & $2.21 \mathrm{E}-04$ & $\mathrm{CC}$ \\
\hline & GO:0006816 & calcium ion transport & 61 & 13 & $1.30 \mathrm{E}-03$ & $\mathrm{BP}$ \\
\hline & GO:0045202 & synapse & 141 & 23 & $1.35 \mathrm{E}-03$ & $\mathrm{CC}$ \\
\hline & GO:0008237 & metallopeptidase activity & 77 & 15 & $1.51 \mathrm{E}-03$ & MF \\
\hline & GO:0031175 & neuron projection development & 59 & 12 & $2.98 \mathrm{E}-03$ & BP \\
\hline & GO:0060395 & SMAD protein signal transduction & 25 & 7 & $3.43 \mathrm{E}-03$ & $\mathrm{BP}$ \\
\hline & GO:0045746 & $\begin{array}{l}\text { negative regulation of Notch signaling } \\
\text { pathway }\end{array}$ & 14 & 5 & 4.19E-03 & $\mathrm{BP}$ \\
\hline & GO:1990869 & cellular response to chemokine & 10 & 4 & $6.66 \mathrm{E}-03$ & $\mathrm{BP}$ \\
\hline & GO:0007155 & cell adhesion & 169 & 24 & $6.81 \mathrm{E}-03$ & $\mathrm{BP}$ \\
\hline & GO:0022008 & neurogenesis & 29 & 7 & 8.31E-03 & BP \\
\hline & GO:0002827 & $\begin{array}{l}\text { positive regulation of T-helper } 1 \text { type } \\
\text { immune response }\end{array}$ & 6 & 3 & $9.49 \mathrm{E}-03$ & $\mathrm{BP}$ \\
\hline \multirow[t]{12}{*}{ TLWB } & GO:0098685 & Schaffer collateral - CA1 synapse & 45 & 15 & 7.05E-07 & $\mathrm{CC}$ \\
\hline & GO:0098978 & glutamatergic synapse & 165 & 31 & $1.48 \mathrm{E}-05$ & $\mathrm{CC}$ \\
\hline & GO:0014069 & postsynaptic density & 82 & 18 & $1.17 \mathrm{E}-04$ & $\mathrm{CC}$ \\
\hline & GO:0045746 & $\begin{array}{l}\text { negative regulation of Notch signaling } \\
\text { pathway }\end{array}$ & 14 & 6 & $5.60 \mathrm{E}-04$ & $\mathrm{BP}$ \\
\hline & GO:0006816 & calcium ion transport & 61 & 13 & $1.34 \mathrm{E}-03$ & $\mathrm{BP}$ \\
\hline & GO:0045202 & Synapse & 141 & 23 & $1.42 \mathrm{E}-03$ & $\mathrm{CC}$ \\
\hline & GO:0032735 & $\begin{array}{l}\text { positive regulation of interleukin- } 12 \\
\text { production }\end{array}$ & 10 & 4 & $6.75 \mathrm{E}-03$ & $\mathrm{BP}$ \\
\hline & GO:0004222 & metalloendopeptidase activity & 73 & 13 & $6.95 \mathrm{E}-03$ & MF \\
\hline & GO:0007155 & cell adhesion & 169 & 24 & 7.13E-03 & $\mathrm{BP}$ \\
\hline & GO:0002827 & $\begin{array}{l}\text { positive regulation of } \mathrm{T} \text {-helper } 1 \text { type } \\
\text { immune response }\end{array}$ & 6 & 3 & $9.59 \mathrm{E}-03$ & $\mathrm{BP}$ \\
\hline & GO:0019855 & calcium channel inhibitor activity & 6 & 3 & $9.59 \mathrm{E}-03$ & MF \\
\hline & GO:1901222 & regulation of NIK/NF-kappaB signaling & 6 & 3 & $9.59 \mathrm{E}-03$ & $\mathrm{BP}$ \\
\hline \multirow[t]{14}{*}{ LMWB } & GO:0060395 & SMAD protein signal transduction & 25 & 10 & $1.64 \mathrm{E}-05$ & BP \\
\hline & GO:0014069 & postsynaptic density & 82 & 18 & $1.18 \mathrm{E}-04$ & $\mathrm{CC}$ \\
\hline & GO:0045202 & synapse & 141 & 25 & $2.52 \mathrm{E}-04$ & $\mathrm{CC}$ \\
\hline & GO:0008237 & metallopeptidase activity & 77 & 16 & $5.35 \mathrm{E}-04$ & MF \\
\hline & GO:0098685 & Schaffer collateral - CA1 synapse & 42 & 10 & $1.99 \mathrm{E}-03$ & $\mathrm{CC}$ \\
\hline & GO:0098978 & glutamatergic synapse & 165 & 25 & 2.61E-03 & $\mathrm{CC}$ \\
\hline & GO:0006816 & calcium ion transport & 16 & 12 & 4.12E-03 & $\mathrm{BP}$ \\
\hline & GO:0045746 & $\begin{array}{l}\text { negative regulation of Notch signaling } \\
\text { pathway }\end{array}$ & 14 & 5 & 4.27E-03 & $\mathrm{BP}$ \\
\hline & GO:0001764 & neuron migration & 64 & 12 & $6.17 \mathrm{E}-03$ & $\mathrm{BP}$ \\
\hline & GO:1990869 & cellular response to chemokine & 10 & 4 & $6.77 \mathrm{E}-03$ & $\mathrm{BP}$ \\
\hline & GO:0007155 & cell adhesion & 169 & 24 & 7.19E-03 & $\mathrm{BP}$ \\
\hline & GO:0022008 & neurogenesis & 29 & 7 & $8.52 \mathrm{E}-03$ & $\mathrm{BP}$ \\
\hline & GO: 1901222 & regulation of NIK/NF-kappaB signaling & 6 & 3 & $9.61 E-03$ & $\mathrm{BP}$ \\
\hline & GO:0050870 & positive regulation of $\mathrm{T}$ cell activation & 11 & 4 & 9.94E-03 & BP \\
\hline
\end{tabular}


168 Especially, SMAD protein signal transduction (GO:0060395), negative regulation of Notch 169 signaling pathway (GO:0045746), and regulation of NIK/NF-kappaB signaling (GO:1901222)

170 showed an overrepresentation of significant genes. In addition, we identified cell adhesion

171 (GO:0007155) and metallopeptidase activity (GO:0008237) GO terms as significant processes that

172 were associated with the composite traits at birth. Several other GO terms were also significant for

173 composite traits at birth. The full list is provided in the Additional file1: Table S1-Table S3.

174 Gene-Set enrichment Analysis of the maternal composite traits at weaning

175 Table 4 shows a set of GO terms that were significantly $(\mathrm{p} \leq 0.01)$ enriched for significant genes 176 associated with weaning traits. Filopodium (GO:0030175) was significantly associated with the 177 composite traits at weaning. Moreover, many GO terms related to protein metabolism were 178 identified, including protein catabolic process (GO:0030163), positive regulation of intracellular 179 protein transport (GO:0090316), protein processing (GO:0016485), and protein localization to 180 plasma membrane (GO:0072659). Several GO terms related to GTPase activity were significant. 181 Among these, GTPase activator activity (GO:0005096) showed an overrepresentation of 182 significant genes associated with the composite traits at weaning. Many significant GO terms were 183 related to ion transport and homeostasis and also channel activity, including cellular calcium ion 184 homeostasis (GO:0006874), ion channel activity (GO:0005216), ion transmembrane transport 185 (GO:0034220), and ion transport (GO:0006811). Also, many GO terms related to lipids, 186 cholesterol, and fatty asides metabolism showed an overrepresentation of genes associated with 187 the traits at weaning, including phospholipid translocation (GO:0045332), lipid phosphorylation 188 (GO:0046834), cholesterol homeostasis (GO:0042632), and fatty acid beta-oxidation 189 (GO:0006635). 
Table 4 Most related Gene Ontology $(\mathrm{GO})$ terms significantly $(\mathrm{p} \leq 0.01)$ enriched using genes associated with ewe composite traits at weaning.

\begin{tabular}{|c|c|c|c|c|c|c|}
\hline Trait & Cat. No. & Term & $\begin{array}{l}\text { No. of genes } \\
\text { in the term }\end{array}$ & $\begin{array}{l}\text { No. of } \\
\text { sig. genes }\end{array}$ & P_value & Ont. \\
\hline \multirow[t]{14}{*}{ PWW } & GO:0030175 & filopodium & 25 & 11 & $1.59 \mathrm{E}-06$ & $\mathrm{CC}$ \\
\hline & GO:0030163 & protein catabolic process & 19 & 8 & $6.51 \mathrm{E}-05$ & $\mathrm{BP}$ \\
\hline & GO:0005096 & GTPase activator activity & 121 & 21 & 7.63E-04 & MF \\
\hline & GO:0005911 & cell-cell junction & 107 & 19 & $1.00 \mathrm{E}-03$ & $\mathrm{CC}$ \\
\hline & GO:0098978 & glutamatergic synapse & 165 & 25 & $1.94 \mathrm{E}-03$ & $\mathrm{CC}$ \\
\hline & GO:0016310 & phosphorylation & 241 & 33 & $2.35 \mathrm{E}-03$ & $\mathrm{BP}$ \\
\hline & GO:0090316 & $\begin{array}{l}\text { positive regulation of intracellular } \\
\text { protein transport }\end{array}$ & 13 & 5 & $2.67 \mathrm{E}-03$ & $\mathrm{BP}$ \\
\hline & GO:0016485 & protein processing & 31 & 8 & $2.81 \mathrm{E}-03$ & $\mathrm{BP}$ \\
\hline & GO:0045332 & phospholipid translocation & 9 & 4 & $4.01 \mathrm{E}-03$ & $\mathrm{BP}$ \\
\hline & GO:0016757 & $\begin{array}{l}\text { transferase activity, transferring } \\
\text { glycosyl groups }\end{array}$ & 112 & 18 & 4.18E-03 & MF \\
\hline & GO:0010628 & positive regulation of gene expression & 207 & 28 & $5.70 \mathrm{E}-03$ & $\mathrm{BP}$ \\
\hline & GO:0008283 & cell proliferation & 82 & 14 & $6.33 \mathrm{E}-03$ & $\mathrm{BP}$ \\
\hline & GO:0042755 & eating behavior & 6 & 3 & $9.03 \mathrm{E}-03$ & $\mathrm{BP}$ \\
\hline & GO:0098609 & cell-cell adhesion & 61 & 11 & $9.78 \mathrm{E}-03$ & $\mathrm{BP}$ \\
\hline \multirow[t]{15}{*}{ TLWW } & GO:0005096 & GTPase activator activity & 121 & 24 & 7.69E-05 & MF \\
\hline & GO:0046834 & lipid phosphorylation & 9 & 5 & $4.25 \mathrm{E}-04$ & $\mathrm{BP}$ \\
\hline & GO:0043547 & positive regulation of GTPase activity & 163 & 26 & $1.40 \mathrm{E}-03$ & BP \\
\hline & GO:0043565 & sequence-specific DNA binding & 291 & 40 & $1.83 \mathrm{E}-03$ & MF \\
\hline & GO:0090316 & $\begin{array}{l}\text { positive regulation of intracellular } \\
\text { protein transport }\end{array}$ & 13 & 5 & $3.24 \mathrm{E}-03$ & $\mathrm{BP}$ \\
\hline & GO:0016485 & protein processing & 31 & 8 & $3.69 \mathrm{E}-03$ & $\mathrm{BP}$ \\
\hline & GO:0006874 & cellular calcium ion homeostasis & 38 & 9 & $3.96 \mathrm{E}-03$ & BP \\
\hline & GO:0030175 & filopodium & 25 & 7 & $3.98 \mathrm{E}-03$ & $\mathrm{CC}$ \\
\hline & GO:0005216 & ion channel activity & 141 & 22 & 4.13E-03 & MF \\
\hline & GO:0045332 & phospholipid translocation & 9 & 4 & $4.71 \mathrm{E}-03$ & BP \\
\hline & GO:0035556 & intracellular signal transduction & 215 & 30 & $5.13 \mathrm{E}-03$ & BP \\
\hline & GO:0034220 & ion transmembrane transport & 110 & 18 & $5.43 \mathrm{E}-03$ & $\mathrm{BP}$ \\
\hline & GO:0006811 & ion transport & 295 & 34 & $7.84 \mathrm{E}-03$ & $\mathrm{BP}$ \\
\hline & GO:0042632 & cholesterol homeostasis & 35 & 8 & $8.11 \mathrm{E}-03$ & $\mathrm{BP}$ \\
\hline & GO:0007275 & multicellular organism development & 107 & 17 & $9.09 \mathrm{E}-03$ & $\mathrm{BP}$ \\
\hline \multirow[t]{12}{*}{ LMWW } & GO:0030175 & filopodium & 25 & 9 & $9.60 \mathrm{E}-05$ & $\mathrm{CC}$ \\
\hline & GO:0005096 & GTPase activator activity & 121 & 23 & $1.07 \mathrm{E}-04$ & MF \\
\hline & GO:0042127 & regulation of cell proliferation & 91 & 18 & 3.49E-04 & BP \\
\hline & GO:0016485 & protein processing & 31 & 9 & $6.06 \mathrm{E}-04$ & $\mathrm{BP}$ \\
\hline & GO:0016310 & phosphorylation & 241 & 34 & $1.19 \mathrm{E}-03$ & $\mathrm{BP}$ \\
\hline & GO:0072659 & $\begin{array}{l}\text { protein localization to plasma } \\
\text { membrane }\end{array}$ & 74 & 14 & $2.38 \mathrm{E}-03$ & $\mathrm{BP}$ \\
\hline & GO:0030163 & protein catabolic process & 19 & 6 & $3.14 \mathrm{E}-03$ & $\mathrm{BP}$ \\
\hline & GO:0098978 & glutamatergic synapse & 165 & 24 & 3.97E-03 & $\mathrm{CC}$ \\
\hline & GO:0035556 & intracellular signal transduction & 215 & 29 & $5.06 \mathrm{E}-03$ & BP \\
\hline & GO:0010628 & positive regulation of gene expression & 207 & 28 & $5.59 \mathrm{E}-03$ & BP \\
\hline & GO:0016301 & kinase activity & 238 & 31 & $6.43 \mathrm{E}-03$ & MF \\
\hline & GO:0006635 & fatty acid beta-oxidation & 18 & 5 & $1.25 \mathrm{E}-02$ & BP \\
\hline
\end{tabular}


194 In addition, terms related to cell proliferation (e.g. GO:0008283 and GO:0042127), gene 195 expression (e.g. GO:0010628), cell adhesion (e.g. GO:0098609), cell junction (e.g. GO:0005911), 196 Protein kinase activity (GO:0016301), and phosphorylation (GO:0016310) were also enriched 197 with significant genes. Several other GO terms were also significant for the traits at weaning. The 198 full list is provided in the Additional file1: Table S4-Table S6.

\section{Discussion}

\section{GWAS and GSA of maternal composite traits at birth}

201

202

203

204

205

206

207

208

209

210

211

212

213

214

215

To attain more consistent findings, two different GWAS approaches were used. Both GWAS approaches identified similar regions that may be explain some part of the genetic variation of studied traits. Four genes, namely RDX, FDX1, ZC3H12C, and ARHGAP2O were identified as maternal genes affecting composite traits at birth on OAR15 (19.7-20.3 Mb). RDX (Radixin) is part of the ERM $(E Z R-R D X-M S N)$ cytoskeleton linker protein family. The expression of ERM proteins in the blastocyst and the uterus has been reported and linked to the implantation potential in mice [13]. Recently EZR and $M S N$ proteins have been detected in the yolk sac [14] and blastocoel fluid of pregnant horses [15] as proteins involved in embryo-maternal interaction. Ferredoxin $(F D X 1)$ is an electron transport intermediate which is functional in mitochondrial cytochromes P450 and is found mainly in the steroidogenic tissues, including testis, adrenal, ovaries, and placenta [16]. ARHGAP2O gene was identified as the candidate gene in both GWAS approaches. High expression of ARHGAP20 in the brain has been reported which proposes a role for this gene product in neurogenesis [17]. Zc3h12c is an endogenous inhibitor of TNF $\alpha$-induced inflammatory signaling in human umbilical vein endothelial cells. It seems the $Z c 3 h 12 c$ gene plays a role in immune regulation in pregnancy [18]. Abdoli et al. (2019) identified a SNP on OAR15 
216 located on $22.02 \mathrm{Mb}$ as a significantly associated SNP with the TLWB trait, which is close to the

217 region identified in this study and reinforces this possibility that this region on OAR15 likely has

218 an effect on fetal development during pregnancy.

219 Our GWA analysis identified a region on OAR7 at 30.2-35.1 Mb that contains three significantly 220 associated SNPs with PBW. This region harbors 12 genes, such as THBS1 and TTBK2. One of 221 these significant SNPs, rs400684038, located within TTBK2 gene. It has been reported that 222 expression of THBS1 by placental cells is crucial for formation of the placental structure [19]. $223 T T B K 2$ gene encodes a serine-threonine kinase that phosphorylates tau and tubulin proteins and is 224 a critical regulator of the initiating the assembly of primary cilia in the embryo [20]. Both GWAS 225 approaches identified a SNP, rs430043751, on OAR23 significantly associated with TLWW. This 226 SNP harbors six genes, including EPG5, PSTPIP2, ATP5F1A, HAUS1, RNF165a, and LOXHD1. 227 EPG5 gene encodes a protein with a crucial role in the autophagy pathway and early differentiation 228 events in human embryonic stem cells [21].

229 Our gene set analysis identified several significantly associated GO terms with maternal composite 230 trait at birth (Table 3). Interestingly many GO terms related to the neural system showed an 231 overrepresentation of significant genes. Numerous studies have reported that the neural alterations 232 in pregnant women's brains are extensive [22, 23]. Noticeably, two pathways (GO:0000045 and 233 GO:0019855) related to calcium ion metabolism enriched by significant genes. It has been shown 234 that placental calcium transfer increases over pregnancy to match fetal needs and ensure 235 appropriate fetal skeletal mineralization [24]. However, recently inconsistent evidence of effects 236 of maternal calcium on birth weight has been reported [25]. Many GO terms related to the immune 237 system, were among significant functional categories. The maternal immune system plays an 238 essential role in a successful pregnancy. A vital balance is needed to protect the mother and fetus 
239 against possible viral or bacterial infections while avoiding fetal rejection [26]. GO terms related

240 to signaling pathways also showed an overrepresentation of significant genes. SMAD protein

241 signal transduction (GO:0060395) was one of these pathways. SMAD proteins transduce signals

242 from TGF- $\beta$ superfamily ligands and as a result, regulate target gene expression. TGF- $\beta$

243 superfamily signaling is vital for female reproduction (Figure 3).

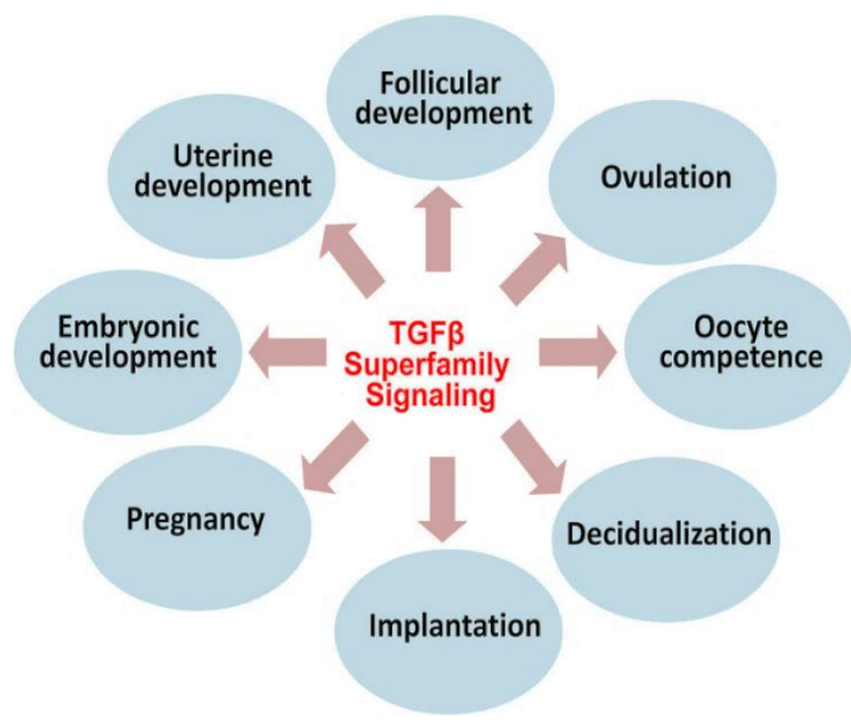

245 Fig. 3 Main functions of TGF- $\beta$ family signaling in female reproduction [27]. SMAD proteins transduce signals from 246 TGF- $\beta$ superfamily ligands.

247 It has been reported that SMAD proteins have a role in maintaining the structural and functional 248 integrity of oviduct and uterus and are essential for the establishment and maintenance of 249 pregnancy [28]. Another signaling pathway was Notch signaling that exerts effects throughout the 250 pregnancy and playing an important role in placental angiogenesis and normal function and also 251 in trophoblast function [29]. NIK/NF-kappaB signaling (GO:1901222) works as a transcription 252 factor involved in inflammatory and immune responses [30]. The effects of NF- $\kappa \mathrm{B}$ and its 253 signaling pathway in the human myometrium during pregnancy and parturition are well reviewed $254[31]$. 


\section{GWAS and GSA of maternal composite traits at weaning}

256 Genes including NDUFA12, NR2C1, FGD6, VEZT, MIR331, and METAP2 were identified on

257 OAR3 around significantly associated SNP (rs428404187) with the composite traits at weaning.

258 This SNP is located in the VEZT gene which has a main role in the cell adhesion process. Cell

259 adhesion process has a widespread effect on mammary glands development and mainly occurs in

260 late pregnancy and partially in the onset of lactation (reviewed in Shamir and Ewald, 2015).

261 Noticeably, we identified the cell-cell adhesion (GO:0098609) pathway as a significant GO term

262 associated with the PWW trait in our gene set analysis. Another gene in this region, $N R 2 C 1$, is a

263 nuclear steroid hormone receptor. This gene acts as a transcription factor and plays an important

264 role in mammary glands differentiation and development in late pregnancy and during lactation

$265[33]$.

266 A SNP, rs398620273, on OAR5 was significantly related to composite traits at weaning and is

267 located within the DTWD2 gene. It is suggested that this gene may be involved in RNA processing

268 [34]. HSD17B4 is another gene that was identified around this SNP and plays an important role in

269 feed intake and food conservation [35]. In dairy cows, it has been reported that feed intake is the

270 major factor limiting milk production in high-yielding dairy cows in early lactation [36]. We

271 identified RPLPO gene on OAR2.Dominant expression of RPLP0 in mammary vasculature tissue

272 has been reported during lactation [37]. The SNORA62 gene was identified on OAR3 as a candidate

273 gene affecting LMWW trait. Recently, a GWAS of milk fatty acid composition identified the

274 SNORA62 gene as a candidate gene affecting milk fatty acid content [38].

275 We identified 24 genes on OAR7 associated with PWW which seven of these genes belong to the 276 pancreatic ribonuclease A family (RNases). It seems that this region plays an important role in 
277 RNA processing. It has been reported that RNASE5 is a functional gene in milk production, 278 specifically milk protein percent [39]. We identified Significant SNP, rs401393221, within the 279 RSU1 gene on OAR13. Using a meta-analysis of microarray data in combination with supervised 280 machine learning models, the RSU1 gene has been identified as DEG during the lactation process 281 in both approaches [40]. It worth to be noted that the RSU1 gene is a member of the milk proteins 282 KEGG pathway. In addition, we identified $C U B N$ and VIM genes around this SNP on OAR13. It 283 has been shown that variation in vitamin B-12 content of bovine milk is associated with the $C U B N$ 284 gene [41]. VIM is a cytoskeletal type III intermediate and has a critical role in mammary gland 285 development [42]. A four-fold increase of VIM protein in lactating tissue compared to resting tissue 286 has been reported [43].

287 A SNP, rs409558668 on OAR16 was identified as significantly $\left(\mathrm{p}=7.95 \times 10^{-5}\right)$ associated SNP with 288 LMWW trait. This SNP located in the TTC23L gene and also harbors PRLR (Prolactin receptor) 289 gene. TTC23L gene is highly expressed during lactation [44] and also identified as a candidate 290 gene that can affect mastitis in Holstein cows [45]. Expression of the PRLR gene in lactating 291 mammary glands has been reported and it is showed that polymorphism in exon 3 and 7 of the $292 P R L R$ gene is correlated with milk production in Holstein cows [46]. In addition, we identified the 293 FTH1 gene on OAR16. The FTH1 gene encodes for the heavy subunit of ferritin. The presence of 294 ferritin in cow's and buffalo's milk has been reported [40, 47].

295 Through gene set analysis for composite traits at weaning, several maternal functional categories 296 were identified. Many GO terms related to protein metabolism and transport and fatty asides 297 metabolism were identified. Recently, in a transcriptome analysis study on buffalo milk, protein 298 metabolism (GO:0019538) pathway identified as a significant term [47]. Changes in the amount 299 of fatty acid synthesis during late-pregnancy and lactation have been long and newly reported for 
300 a variety of species including the rat, rabbit, pig, and cow [48, 49]. Terms related to calcium and

301 other ions metabolism and transport were also significant. Several different comparative

302 transcriptome analyses have reported the role of calcium metabolism-related pathways in the

303 lactation process [47, 50]. Phosphorylation (GO:0016310) term was identified as a significant

304 pathway associated with PWW and LMWW traits. Caseins comprising $80 \%$ of the proteins in

305 cow's and sheep's milk and phosphorylation by Casein Kinase enzyme is a crucial step for milk

306 production in the lactating mammary gland [51]. Noticeably, the kinase activity (GO:0016301)

307 pathway was another significant term for LMWW that catalysis the transfer of a phosphate group

308 to a substrate molecule. The cell-cell adhesion pathway was significantly associated with PWW.

309 The effects of cell adhesion molecules on the lactogenesis process have been well-reviewed [52].

310 Noticeably, the VEZT gene, one of our identified genes in GWA analysis, is a member of this

311 pathway. GTPase activator activity (GO:0005096) GO term was identified as a significant

312 pathway related to the composite traits at weaning. GTPases are known to be involved in numerous

313 secretory processes and play an important role in translation and translocation of proteins,

314 secretion of the milk fat globule, and probably other milk components [47]. Many GO terms

315 associated with cell proliferation and differentiation were also detected as significant. Most

316 mammary growth takes place through pregnancy. Mammary gland cell proliferation and

317 differentiation have a great impact on milk yield and lactation persistency [53]. As expected, must

318 identified genes and GO terms have a role in milk production or mammary gland development

319 which means feeding lambs by milk have the most impact on weight gain rather than other 320 maternal effects.

321 Conclusions 
322 In this study, we complemented the GWAS with gene set enrichment analysis (GSEA) to find

323 genes and pathways affecting maternal composite traits at birth and weaning in sheep. Some

324 maternal genes RDX, FDX1, ARHGAP20, ZC3H12C, THBS1, and EPG5 were associated with

325 composite traits at birth. These genes play roles in pregnancy e.g. autophagy, immune response,

326 angiogenesis, and placental formation. Gene set analysis identified calcium ion transport GO term

327 as a significant pathway affecting the composite traits at birth. In addition, we identified many

328 genes (e.g., NR2C1, VEZT, HSD17B4, RSU1, CUBN, VIM, PRLR, and FTH1) as maternal genes

329 affecting composite traits at weaning. Our gene set analysis for these traits identified several

330 significantly associated GO terms such as protein processing and transport, phospholipid

331 translocation, ion transport, and cell-cell adhesion. Most of the identified genes and pathways are

332 involved in mammary glands differentiation and development and also in milk components

333 production. The results provide a good insight into how maternal genes and pathways influence

334 progeny weight at birth and weaning and elucidate the mechanisms underlying these complex traits 335 in sheep.

336 Methods

337 Phenotypic and Genotypic Data

338 The data set consisted of 3916 and 3635 birth weight and weaning weight (90 days of age) records, 339 respectively. Progeny birth weight (PBW), litter mean weight at birth (LMWB) and total litter 340 weight at birth (TLWB) were used as maternal composite traits at birth. Also, progeny weaning 341 weight (PWW), litter mean weight at weaning (LMWW) and total litter weight at weaning 342 (TLWW) were considered as maternal composite traits at weaning. LMWB and LMWW are 343 arithmetic mean of TLWB and TLWW traits and were calculated for each lambing per ewes. The 
344 pedigree file included 4727 animals with 178 sires, 1509 dams and 818 founders. Data were

345 collected from 2004 to 2012 (9-year span) at Abbas Abad Baluchi sheep Breeding Station, located

346 in Sarakhs city, Khorasan Razavi province, Iran. Descriptive statistics of studied traits are

347 presented in Table 5.

Table 5 Descriptive statistics of studied traits.

\begin{tabular}{lllllll}
\hline Trait & N & Ave & Min & Max & CV & Total N (EBV analysis) \\
\hline PBW & 436 & 4.26 & 2.30 & 6.80 & 0.17 & 3916 \\
TLWB & 317 & 5.90 & 2.80 & 13.00 & 0.30 & 3063 \\
LMWB & 317 & 4.40 & 2.70 & 6.80 & 0.17 & 3063 \\
PWW & 398 & 20.31 & 9.10 & 34.60 & 0.20 & 3635 \\
TLWW & 294 & 27.52 & 9.90 & 57.80 & 0.30 & 2869 \\
LMWW & 294 & 20.97 & 9.90 & 34.60 & 0.19 & 2869
\end{tabular}

PBW, Progeny Birth Weight; TLWB, Total Litter Weight at Birth; LMWB, Litter Mean Weight at Birth; PWW, Progeny Weaning Weight; TLWW, Total Litter Weight at Weaning; LMWW, Litter Mean Weight at Weaning. N, number of records; Ave, Average; Var, Variance; SD, Standard deviation; CV, Coefficient of variation; Total N, Total number of observations used for EBVs calculation.

352 SNP genotype data of 54,241 genomic position were provided for 91 ewes by animal genetic group 353 of Sari Agriculture Science and Natural Resource University (SANRU), Iran [54]. GenABEL 354 package [55] was used for quality control in R software (R Core Team, 2019). Those SNP markers 355 with unknown genomic location, or were monomorphic, or had minor allele frequency and 356 genotype call rate less than 0.01 and 93\%, respectively, and SNPs that departed from Hardy357 Weinberg equilibrium (for a P-value cut-off of $1 \times 10^{-6}$ ) were removed from the dataset. As well as, 358 ewes with a genotyping call rate less than 95\%, removed from the dataset. After quality control, 35984 ewes and 45342 SNPs were retained for the analysis.

Genome-wide association study

361 Long-term monitoring of some traits, commonly include repeated measures of individuals and 362 allows estimation of year and age effects over time. In this study, we performed the GWAS in two 363 different ways, (i) Phenotypes were used as the response variable, (ii) EBVs were used as the 364 response variable. 


\section{Genome-wide association mapping using phenotypes (pGWAS)}

366 For the GWAS using phenotypes, repeatability model was extended as below,

$$
y=X b+X_{S N P} \beta_{S N P}+Z u+W p e+e
$$

368

369

370

371

372

373

374

375

376

377

378

379

380

381 where $\boldsymbol{y}$ is a vector of ewe's progenies weights; $\boldsymbol{b}$ is a vector of fixed effects; $\boldsymbol{u}$ is the vector of random direct additive genetic effects, $\boldsymbol{p} \boldsymbol{e}$ is the vector of permanent environmental effects, and $\boldsymbol{e}$ is the vector of random residual effects. The matrices $\mathbf{X}, \mathbf{Z}$, and $\mathbf{W}$ are the design matrices relating individuals' phenotypic records to their fixed and random effects, respectively. $\mathbf{X}_{\mathrm{SNP}}$ is the incidence matrix for the SNP markers and $\boldsymbol{\beta}_{\mathrm{SNP}}$ is the regression coefficient. In this case, the random effects have multivariate Gaussian (co)variance,

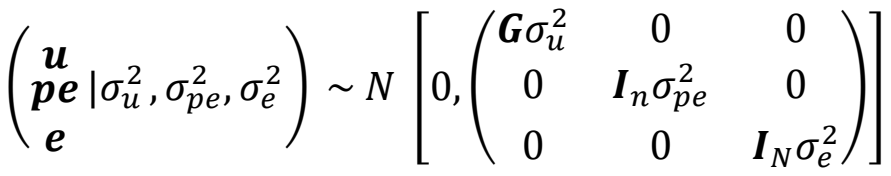

Where $\mathbf{G}$ is the genomic relationship matrix, $\mathbf{I}$ is the identity matrix, $n$ is the number of genotyped individuals with reproductive records ( $n=84$, after QC) and $N$ is the total number of observations for genotyped individuals ( $N=294-436$, depends on the trait). We can write the extended repeatability model as below,

This model is the same as the above model if,

$$
y=X b+X_{S N P} \beta_{S N P}+e
$$

$$
\boldsymbol{e} \sim N(0, \boldsymbol{V}) \text { where } \mathbf{V}=\boldsymbol{Z} \boldsymbol{G} \boldsymbol{Z}^{\prime} \sigma_{u}^{2}+\boldsymbol{W} \boldsymbol{W}^{\prime} \sigma_{p e}^{2}+\boldsymbol{I}_{N} \sigma_{e}^{2}
$$

382 In this approach, the P-value for the SNP effects in the original model can be calculated from the 383 ratio of the $\beta_{\text {SNP }}$ and its standard error (Wald test). An alternative approach is to use the following 
384 score test statistic that is more computationally efficient, asymptotically standard normal and 385 approximates the Wald test,

$$
\boldsymbol{Z}=\frac{\boldsymbol{X}_{S N P}^{\prime} \boldsymbol{V}_{\circ}^{-1}(\boldsymbol{y}-\boldsymbol{X} \widehat{\boldsymbol{\beta}})}{\sqrt{\boldsymbol{X}_{S N P}^{\prime} \boldsymbol{V}_{\circ}^{-1}} \boldsymbol{X}_{S N P}}
$$

387 but here $\boldsymbol{V}$ 。computed same as $\boldsymbol{V}$ using a model where the SNP effects $\boldsymbol{X}_{S N P} \boldsymbol{\beta}_{S N P}$ has been excluded 388 and $\widehat{\boldsymbol{\beta}}$ is computed from the model $\boldsymbol{y}=\boldsymbol{X} \boldsymbol{b}+\boldsymbol{X}_{\boldsymbol{S N P}} \boldsymbol{\beta}_{\boldsymbol{S N P}}+\boldsymbol{e}$, assuming $\boldsymbol{e} \sim N\left(0, \boldsymbol{V}_{\circ} \sigma_{e}^{2}\right)$. The 389 analyses were performed using the R package RepeatABEL [56].

390 Genome-wide association mapping using estimated breeding values (eGWAS)

391 In this approach, at first, we ran a pedigree-BLUP analysis using the classical repeatability animal 392 model in BLUPF90 software [57] and breeding values of animals were estimated for all traits. 393 Lambs' sex, lamb birth year, and dam's age at lambing included in the model as fixed effects. 394 Animal direct additive genetic and ewe permanent environmental effects were used as random 395 effects. Variance components were estimated using the Restricted Maximum Likelihood (REML) 396 approach, implemented in the AIREMLF90 software [57]. At the next step, EBVs were considered 397 as the response variable and SNPs genotypes fitted in a GLM model as shown below,

$$
E B V S=X_{S N P} \beta_{S N P}+e
$$

399 where $\boldsymbol{X}_{S N P}$ is the design matrix relating EBVs to SNP genotypes and $\boldsymbol{\beta}_{\mathrm{SNP}}$ is the regression 400 coefficient. GenABEL [55] package in the R environment was used for this analysis. Due to the 401 use of the genomic and pedigree-based relationship matrix in GWA analysis, p-values were almost 402 non-inflated $(1.01 \leq \lambda \leq 1.07)$ for all traits, however, partial inflation was corrected using genomic 
403 control (GC) method and all p-values presented without any inflation ( $\lambda=1)$. CMplot 404 (https://github.com/YinLiLin/R-CMplot) R package was used to drawing Manhattan plots.

405 Gene annotation

406 Some well-known databases including BioMart-Ensembl (www.ensembl.org/biomart), UCSC 407 Genome Browser (http://genome.ucsc.edu) and National Center for Biotechnology Information 408 (https://www.ncbi.nlm.nih.gov) were used along with the Ovis aries reference genome assembly 409 (Oar_v3.1) to identify candidate genes within a window of $300 \mathrm{~kb}$ up and downstream of the 410 significant SNPs. The distance of $300 \mathrm{~kb}$ was selected according to the results of linkage 411 disequilibrium analysis.

\section{Gene-set enrichment and pathway-based analysis}

413 Gene set enrichment analysis can be performed in three steps: (i) the assignment of SNPs to the

414 known genes, (ii) the assignment of genes to functional categories, (iii) the association analysis 415 between each functional category and studied phenotypes.

416 For each trait, a threshold of P-values < 0.05 was applied to determine significant SNPs (based on 417 the results of the pGWAS) for enrichment analysis. The Bioconductor R package biomaRt [58, 418 59] and the Oar_v3.1 ovine reference genome assembly were used to flagging genes by significant 419 SNPs. SNPs were assigned to genes if they were within the genomic region or $15 \mathrm{~kb}$ up and 420 downstream of an annotated gene. Genes harboring at least one significant SNP were considered 421 as significantly associated genes.

422 Gene Ontology (GO) database [60] was used to define the functional sets of genes. The GO 423 database classifies genes into three functional categories (biological process, molecular function, 
424 and cellular component) based on their common properties. Finally, the significant association of

425 a particular GO term with maternal composite traits was calculated using Fisher's exact test based

426 on the hypergeometric distribution. The P-value of observing $g$ significant genes in the term was

427 computed using the following formula,

428

$$
P-\text { value }=1-\sum_{i=0}^{g-1} \frac{\left(\begin{array}{l}
S \\
i
\end{array}\right)\left(\begin{array}{c}
m-S \\
k-i
\end{array}\right)}{\left(\begin{array}{l}
M \\
k
\end{array}\right)}
$$

429 where $s$ is the total number of significant genes associated with a given maternal composite trait

430 at birth or weaning, $m$ is the total number of analyzed genes, and $k$ is the total number of genes in

431 the term under consideration [10]. The GO enrichment analysis was performed using the R

432 package goseq [61]. GO terms with more than 5 and less than 500 genes were tested. Functional

433 categories with a nominal P-value less than or equal to $0.01(\mathrm{p} \leq 0.01)$ considered as significant

434 categories.

435 Abbreviations

436 Cat. No: Category number

437 Chr: Chromosome

438 eGWAS: GWAS using EBVs as response variable.

439 GO: Gene Ontology

440 GSEA: Gene set enrichment analysis

441 GWAS: Genome-wide association study

442 LMWB: litter mean weight at birth 
443 LMWW: litter mean weight at weaning

444 Ont: Ontology

445 PBW: progeny birth weight

446 pGWAS: GWAS using phenotypes as response variable

447 PWW: progeny weaning weight

448 TLWB: total litter weight at birth

449 TLWW: total litter weight at weaning

450 Declarations

451 Ethics approval and consent to participate

452 Consent for publication

453 Not applicable.

454 Availability of data and materials

455 Competing interests

456 The authors declare that they have no competing interests.

$457 \quad$ Funding

458 Authors' contributions 
459 ME, RAA designed the research. ME performed data analysis, interpreted the data and wrote the 460 manuscript. MG, collected the samples and Genotyped. RAA, MG, SHH edited the manuscript.

461 All authors have read and approved the final manuscript.

462 Acknowledgements

463 Not applicable

464 Authors' information (optional)

465 Affiliations

466 Mehdi Esmaeilifard, Seyed Hasan Hafezian, Mohsen Gholizadeh, Rostam Abdollahi-Arpanahi

467 Ph.D. Graduate, Department of animal science and fisheries, Sari Agricultural Sciences and 468 Natural Resources University (SANRU), Sari, Iran.

469 Associate Professor, Department of animal science and fisheries, Sari Agricultural Sciences and 470 Natural Resources University (SANRU), Sari, Iran.

471 Associate Professor, Department of animal science and fisheries, Sari Agricultural Sciences and 472 Natural Resources University (SANRU), Sari, Iran.

473 Researcher assistant, Department of Animal Sciences, University of Florida, Gainesville, FL, 474 United States.

475 Corresponding author

476 Correspondence to Mehdi Esmaeilifard. 


\section{Supplementary information}

479 Additional file1: List of significantly associated GO terms with the studied traits.

480 References

481 1. Hanford KJ, Van Vleck LD, Snowder GD. Estimates of genetic parameters and genetic change for 482 reproduction, weight, and wool characteristics of Targhee sheep. J Anim Sci. 2003;81(3):630-40.

483 2. Wang CT, Dickerson GE. Simulation of life-cycle efficiency of lamb and wool production for genetic levels 484 of component traits and alternative management options. J Anim Sci. 1991 Nov;69(11):4324-37.

485 3. Duguma G, Schoeman SJ, Cloete SWP, Jordaan GF. Genetic and environmental parameters for ewe 486 productivity in Merinos. S Afr J Anim Sci. 2002;32(3):154-9.

487 4. Snowder GD, Fogarty NM. Composite trait selection to improve reproduction and ewe productivity: a review. Anim Prod Sci. 2009;49(1):9-16.

489 5. Bromley CM, Van Vleck LD, Snowder GD. Genetic correlations for litter weight weaned with growth, 490 prolificacy, and wool traits in Columbia, Polypay, Rambouillet, and Targhee sheep. J Anim Sci. 2001;79(2):339-46.

6. Abdoli R, Mirhoseini S, Ghavi Hossein-Zadeh N, Zamani P, Ferdosi M, Gondro C. Genome-wide association study of four composite reproductive traits in Iranian fat-tailed sheep. Reprod Fertil Dev [Internet]. 2019 [cited 2019 Aug 31];31:1127-33. Available from: http://www.publish.csiro.au/RD/RD18282

496 7. Abbasi MA, Abdollahi-Arpanahi R, Maghsoudi A, Torshizi RV, Nejati-Javaremi A. Evaluation of models for estimation of genetic parameters and maternal effects for early growth traits of Iranian Baluchi sheep. Small Rumin Res [Internet]. 2012 May 1 [cited 2019 Aug 21];104(1-3):62-9. Available from: https://www.sciencedirect.com/science/article/abs/pii/S0921448811004056 

in dairy cattle. J Dairy Sci. 2017;100(2):1223-31.

503

9. Wang L, Jia P, Wolfinger RD, Chen X, Zhao Z. Gene set analysis of genome-wide association studies: methodological issues and perspectives. Genomics. 2011;98(1):1-8.

10. Han Y, Peñagaricano F. Unravelling the genomic architecture of bull fertility in Holstein cattle. BMC Genet. 2016;17(1):143.

11. Neupane M, Kiser JN, Team the BRDCCAPR, Neibergs HL. Gene set enrichment analysis of SNP data in dairy and beef cattle with bovine respiratory disease. Anim Genet [Internet]. 2018 Dec 1;49(6):527-38. Available from: https://doi.org/10.1111/age.12718

12. Moradband F, Rahimi G, Gholizadeh M. Association of polymorphisms in fecundity genes of GDF9, BMP15 and BMP15-1B with litter size in Iranian Baluchi sheep. Asian-Australasian J Anim Sci. 2011;24(9):1179-83.

13. Matsumoto H, Daikoku T, Wang H, Sato E, Dey SK. Differential Expression of Ezrin/Radixin/Moesin (ERM) and ERM-Associated Adhesion Molecules in the Blastocyst and Uterus Suggests Their Functions During Implantation1. Biol Reprod [Internet]. 2004 Mar 1;70(3):729-36. Available from: https://doi.org/10.1095/biolreprod.103.022764

14. Smits K, Willems S, Van Steendam K, Van De Velde M, De Lange V, Ververs C, et al. Proteins involved in embryo-maternal interaction around the signalling of maternal recognition of pregnancy in the horse. Sci Rep. 2018;8(1):5249.

15. Swegen A, Grupen CG, Gibb Z, Baker MA, de Ruijter-Villani M, Smith ND, et al. From peptide masses to pregnancy maintenance: a comprehensive proteomic analysis of the early equine embryo secretome, blastocoel fluid, and capsule. Proteomics. 2017;17(17-18):1600433.

16. Sheftel AD, Stehling O, Pierik AJ, Elsässer H-P, Mühlenhoff U, Webert H, et al. Humans possess two mitochondrial ferredoxins, Fdx1 and Fdx2, with distinct roles in steroidogenesis, heme, and Fe/S cluster biosynthesis. Proc Natl Acad Sci. 2010;107(26):11775-80. 
526 17. Kalla C, Nentwich H, Schlotter M, Mertens D, Wildenberger K, Döhner H, et al. Translocation t (X; 11)(q13; q23) in B-cell chronic lymphocytic leukemia disrupts two novel genes. Genes, Chromosom Cancer. 2005;42(2):128-43.

18. Liu L, Zhou Z, Huang S, Guo Y, Fan Y, Zhang J, et al. Zc3h12c inhibits vascular inflammation by repressing $\mathrm{NF}-\kappa \mathrm{B}$ activation and pro-inflammatory gene expression in endothelial cells. Biochem J. 2013;451(1):55-60.

19. Ostankova Y V, Klimovskaya YS, Gorskaya OA, Kolobov A V, Kvetnoi IM, Selkov SA, et al. Expression of thrombospondin-1 gene mRNA and protein in the placenta in gestosis. Bull Exp Biol Med. $2011 ; 151(2): 215-8$.

20. Goetz SC, Liem Jr KF, Anderson K V. The spinocerebellar ataxia-associated gene Tau tubulin kinase 2 controls the initiation of ciliogenesis. Cell. 2012;151(4):847-58.

21. Tra T, Gong L, Kao L-P, Li X-L, Grandela C, Devenish RJ, et al. Autophagy in human embryonic stem cells. PLoS One. 2011;6(11):e27485.

22. Cohen L, Mizrahi A. Plasticity during motherhood: changes in excitatory and inhibitory layer $2 / 3$ neurons in auditory cortex. J Neurosci. 2015;35(4):1806-15.

541 23. Bridges RS. Long-term alterations in neural and endocrine processes induced by motherhood in mammals. Horm Behav. 2016;77:193-203.

543 24. Strid H, Powell TL. ATP-dependent Ca 2+ transport is up-regulated during third trimester in human syncytiotrophoblast basal membranes. Pediatr Res. 2000;48(1):58.

545

25. Thompson WD, Tyrrell J, Borges M-C, Beaumont RN, Knight BA, Wood AR, et al. Association of maternal 546 circulating $25(\mathrm{OH}) \mathrm{D}$ and calcium with birth weight: A mendelian randomisation analysis. PLoS Med. 2019;16(6):e1002828. Front Immunol. 2019;10. 
550 27. Li Q. Transforming growth factor $\beta$ signaling in uterine development and function. J Anim Sci Biotechnol. 2014;5(1):52.

552 28. Rodriguez A, Tripurani SK, Burton JC, Clementi C, Larina I, Pangas SA. SMAD signaling is required for structural integrity of the female reproductive tract and uterine function during early pregnancy in mice. Biol Reprod. 2016;95(2):41-4.

29. Zhao W-X, Lin J-H. Notch signaling pathway and human placenta. Int J Med Sci. 2012;9(6):447.

556

30. Baldwin Jr AS. The NF-кB and IкB proteins: new discoveries and insights. Annu Rev Immunol. 1996;14(1):649-81.

31. Cookson VJ, Chapman R. NF-kB function in the human myometrium during pregnancy and parturition. Histol Histopathol. 2010;

32. Shamir ER, Ewald AJ. Adhesion in mammary development: novel roles for E-cadherin in individual and collective cell migration. In: Current topics in developmental biology. Elsevier; 2015. p. 353-82.

33. To B, Andrechek ER. Transcription factor compensation during mammary gland development in E2F knockout mice. PLoS One. 2018;13(4):e0194937.

34. Burroughs AM, Aravind L. Analysis of two domains with novel RNA-processing activities throws light on the complex evolution of ribosomal RNA biogenesis [Internet]. Vol. 5, Frontiers in Genetics . 2014. p. 424. Available from: https://www.frontiersin.org/article/10.3389/fgene.2014.00424

35. Salleh MS, Mazzoni G, Höglund JK, Olijhoek DW, Lund P, Løvendahl P, et al. RNA-Seq transcriptomics and pathway analyses reveal potential regulatory genes and molecular mechanisms in high-and low-residual feed intake in Nordic dairy cattle. BMC Genomics. 2017;18(1):258.

36. Johansen M, Lund P, Weisbjerg MR. Feed intake and milk production in dairy cows fed different grass and legume species: A meta-analysis. animal. 2018;12(1):66-75.

37. Lee NK, kook Kim M, Choi JH, Kim EB, Lee HG, Kang SK, et al. Identification of a peptide sequence targeting mammary vasculature via RPLP0 during lactation. Peptides. 2010;31(12):2247-54. 
574 38. Palombo V, Milanesi M, Sgorlon S, Capomaccio S, Mele M, Nicolazzi E, et al. Genome-wide association study of milk fatty acid composition in Italian Simmental and Italian Holstein cows using single nucleotide polymorphism arrays. J Dairy Sci. 2018 Dec 1;101(12):11004-19.

577

39. Raven L-A, Cocks BG, Pryce JE, Cottrell JJ, Hayes BJ. Genes of the RNASE5 pathway contain SNP associated with milk production traits in dairy cattle. Genet Sel Evol. 2013;45(1):25.

579

40. Farhadian M, Rafat SA, Hasanpur K, Ebrahimi M, Ebrahimie E. Cross-species meta-analysis of transcriptomic data in combination with supervised machine learning models identifies the common gene signature of lactation process. Front Genet. 2018;9:235.

41. Rutten MJM, Bouwman AC, Sprong RC, van Arendonk JAM, Visker MHPW. Genetic variation in vitamin

42. Peuhu E, Virtakoivu R, Mai A, Wärri A, Ivaska J. Epithelial vimentin plays a functional role in mammary gland development. Development. 2017;144(22):4103-13.

43. Michalczyk A, Ackland ML, Brown RW, Collins JP. Lactation affects expression of intermediate filaments in human breast epithelium. Differentiation. 2001;67(1-2):41-9.

44. Paten AM. Maternal nutritional programming in the sheep: effects on post-natal growth, mammogenesis and lactation in adult-ewe offspring: a thesis submitted for the degree of Doctor of Philosophy in Animal Science at Massey University, Palmerston North, Aotearoa Ne. Massey University; 2014.

45. Tiezzi F, Parker-Gaddis KL, Cole JB, Clay JS, Maltecca C. A genome-wide association study for clinical mastitis in first parity US Holstein cows using single-step approach and genomic matrix re-weighting procedure. PLoS One. 2015;10(2):e0114919.

46. Zhang J, Zan L, Fang P, Zhang F, Shen G, Tian W. Genetic variation of PRLR gene and association with milk performance traits in dairy cattle. Can J Anim Sci. 2008;88(1):33-9.

597 47. Arora R, Sharma A, Sharma U, Girdhar Y, Kaur M, Kapoor P, et al. Buffalo milk transcriptome: A 
48. Larson BL, Smith VR. Lactation. A comprehensive treatise. Vol. II. Biosynthesis and secretion of milk/Diseases. Academic Press.; 1974.

49. Abdollahi-Arpanahi R, Carvalho MR, Ribeiro ES, Peñagaricano F. Association of lipid-related genes implicated in conceptus elongation with female fertility traits in dairy cattle. J Dairy Sci. 2019;102(11):10020-9.

50. Bhat SA, Ahmad SM, Ibeagha-Awemu EM, Bhat BA, Dar MA, Mumtaz PT, et al. Comparative transcriptome analysis of mammary epithelial cells at different stages of lactation reveals wide differences in

51. Bionaz M, Hurley W, Loor J. Milk protein synthesis in the lactating mammary gland: Insights from transcriptomics analyses. Milk protein. 2012;285-324.

52. Morrison B, Cutler M Lou. The contribution of adhesion signaling to lactogenesis. J Cell Commun Signal. 2010;4(3):131-9.

53. Davis SR. TRIENNIAL LACTATION SYMPOSIUM/BOLFA: Mammary growth during pregnancy and lactation and its relationship with milk yield. J Anim Sci. 2017;95(12):5675-88.

54. Gholizadeh M, Rahimi-Mianji G, Nejati-Javaremi A, De Koning DJ, Jonas E. Genomewide association study to detect QTL for twinning rate in Baluchi sheep. J Genet. 2014 Aug;93(2):489-93.

55. Aulchenko YS, Ripke S, Isaacs A, Van Duijn CM. GenABEL: an R library for genome-wide association analysis. Bioinformatics. 2007;23(10):1294-6. genome wide association studies in natural populations using repeated measures-evaluation and implementation. Methods Ecol Evol. 2016;7(7):792-9. 
programs. 2018.

623 58. Durinck S, Moreau Y, Kasprzyk A, Davis S, De Moor B, Brazma A, et al. BioMart and Bioconductor: a 624 powerful link between biological databases and microarray data analysis. Bioinformatics.

$625 \quad 2005 ; 21(16): 3439-40$.

626 59. Durinck S, Spellman PT, Birney E, Huber W. Mapping identifiers for the integration of genomic datasets with the R/Bioconductor package biomaRt. Nat Protoc. 2009;4(8):1184.

628 60. Ashburner M, Ball CA, Blake JA, Botstein D, Butler H, Cherry JM, et al. Gene ontology: tool for the unification of biology. Nat Genet. 2000;25(1):25.

630

61. Young MD, Wakefield MJ, Smyth GK, Oshlack A. Gene ontology analysis for RNA-seq: accounting for 631 selection bias. Genome Biol. 2010;11(2):R14. 


\section{Figures}

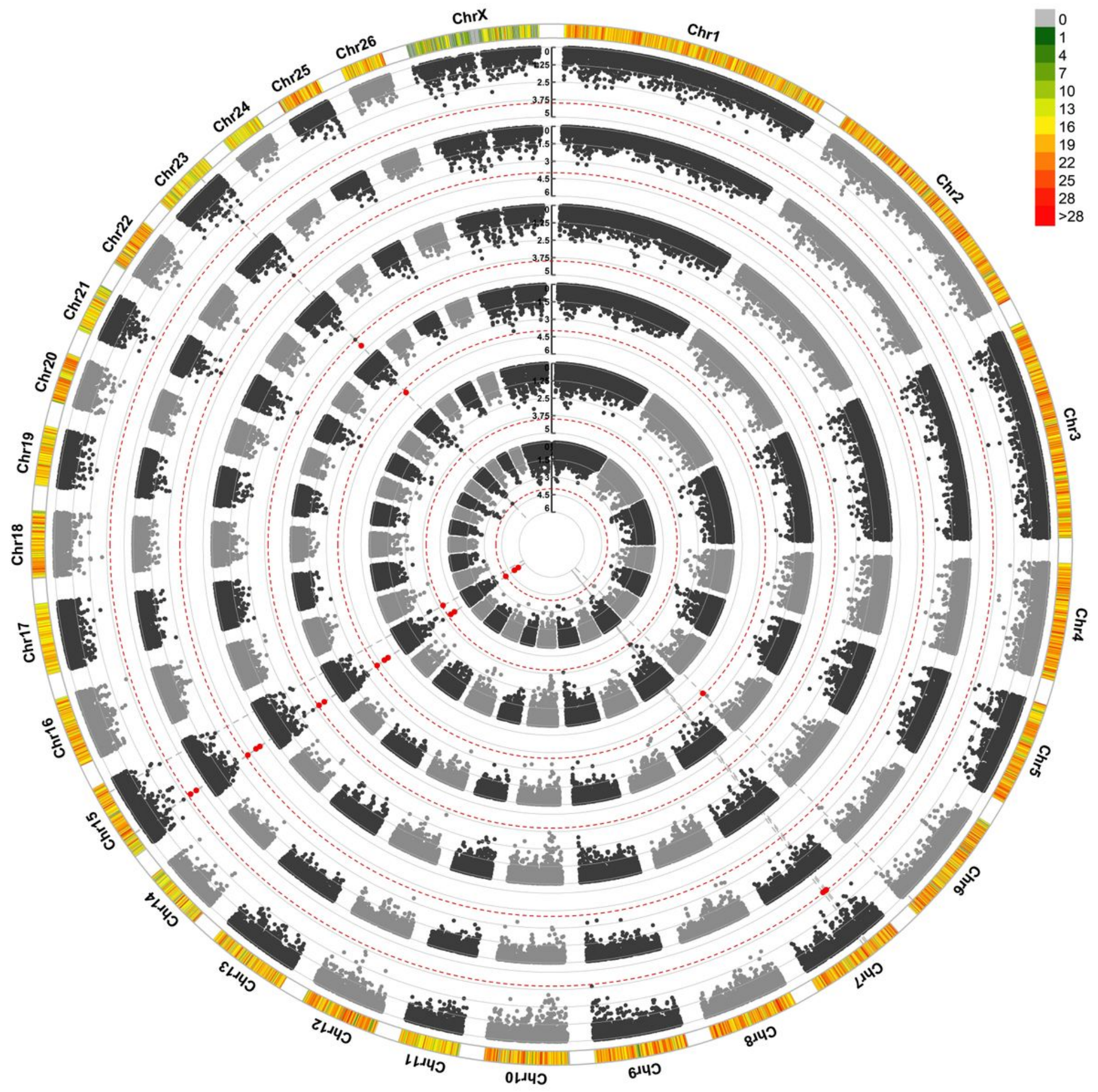

Figure 1

Circular Manhattan plot for associations of SNPs with ewe composite traits at birth by two GWAS approaches. The 6 circles from outside to inside represent Progeny Birth Weight (PBW): pGWAS and eGWAS; Total Litter Weight at Birth (TLWB): pGWAS and eGWAS; Litter Mean Weight at Birth (LMWB): pGWAS and eGWAS. X-axis: SNPs positions on chromosomes, Y-axis: -Log10 P-value. The dashed lines 
indicate the threshold for statistical significance $(P<10-4)$. The outermost circle show SNPs density in 1 $\mathrm{Mb}$ window for each chromosome. pGWAS: GWAS using phenotypes as response variable; eGWAS: GWAS using EBVs as response variable.

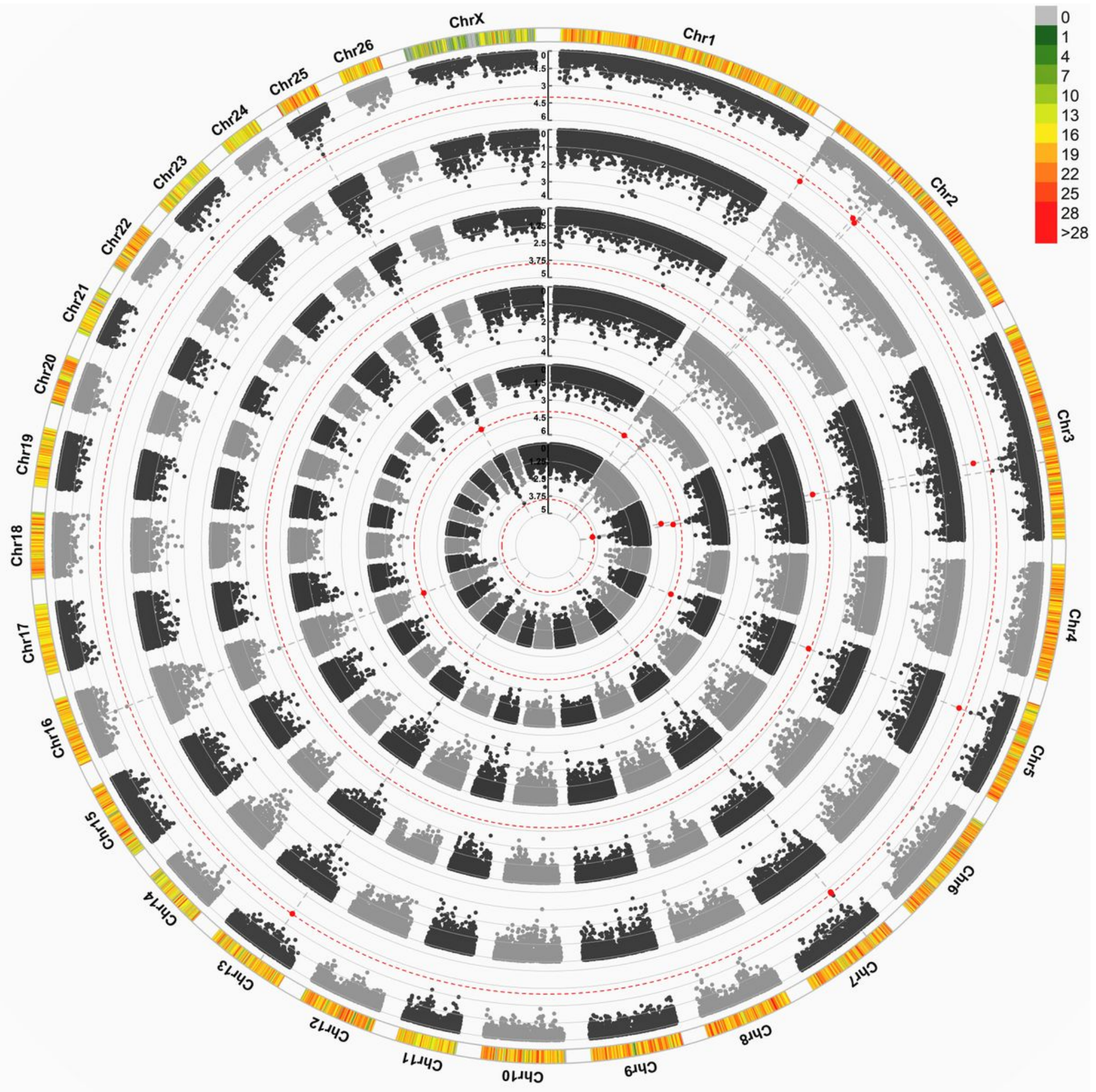

Figure 2

Circular Manhattan plot for associations of SNPs with ewe composite traits at weaning by two GWAS approaches. The 4 circles, from outside to inside, represent Progeny Weaning Weight (PWW): pGWAS and eGWAS; Total Litter Weight at Weaning (TLWW): pGWAS and eGWAS; Litter Mean Weight at Weaning 
(LMWW): pGWAS and eGWAS. X-axis: SNPs positions on chromosomes, Y-axis: -Log10 P-value. The dashed lines indicate the threshold for statistical significance $(P<10-4)$. The outermost circle show SNPs density in $1 \mathrm{Mb}$ window for each chromosome. pGWAS: GWAS using phenotypes as response variable; eGWAS: GWAS using EBVs as response variable.

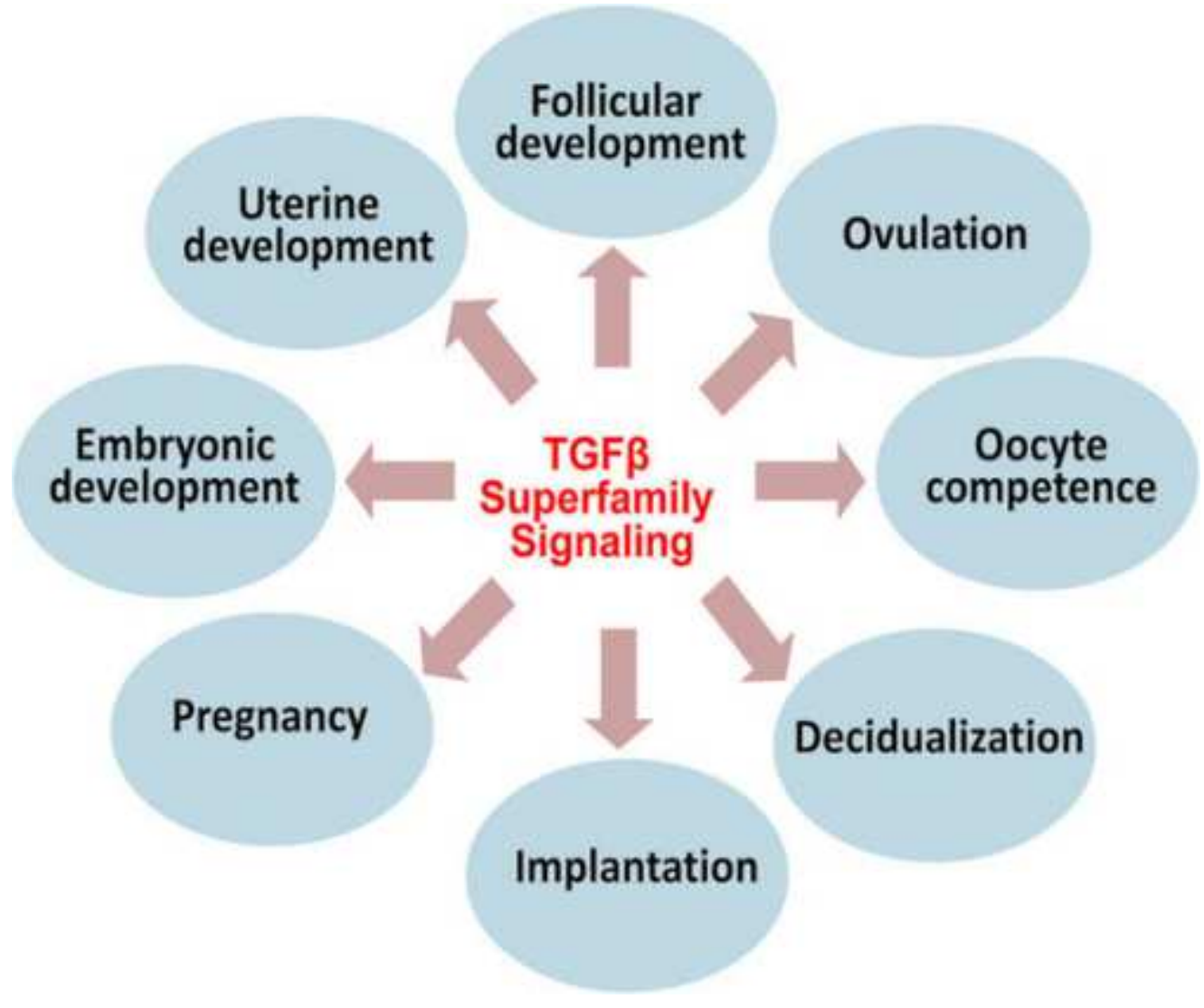

Figure 3

Main functions of TGF- $\beta$ family signaling in female reproduction [27]. SMAD proteins transduce signals from TGF- $\beta$ superfamily ligands.

\section{Supplementary Files}

This is a list of supplementary files associated with this preprint. Click to download.

- Additionalfile1.xlsx 